\title{
EPHRAIM THE SYRIAN IN ANGLO-SAXON ENGLAND
}

\author{
JANE STEVENSON \\ CENTRE FOR BRITISH AND COMPARATIVE STUDIES \\ THE UNIVERSITY OF WARWICK \\ UNITED KINGDOM
}

[1] The Anglo-Saxon church was of complex origin: it owed much to Christian Ireland, and much to informal and semi-formal contact with Frankia. But above all (especially as presented by that great mythographer, Bede), it owed its beginnings to Rome, and in particular, to that most Roman of early Popes, Gregory the Great. The Christianisation of the Anglo-Saxons got under way in the late sixth century, and was consolidated in the seventh: the period in which the Eastern and Western halves of Christendom went their separate ways, and the West almost entirely stopped using Greek. The seventh century is also the century of Mohammed, in which most Syriac-speaking Christians found themselves forcibly separated from their Byzantine neighbours. So there is a whole series of good reasons why we would not expect to find Syriac influence on this young church in the distant West. But despite all this, there is one father of the Syrian church who was known in England, both by name, and for his actual work; it was, of course, St. Ephraim, the only early Syriac church father to have some of his works translated into Greek, and from Greek, into Latin. Quite a number of works attributed to Ephraim, sometimes wrongly, circulated in the West in the early middle ages. The interesting thing about Ephraim in Anglo-Saxon England, as we shall see, is that not only did pseudo-Ephraimic texts circulate there, there is a very real possibility that some genuine works of Ephraim came to this island. 
The idea that Ephraim's work might have influenced the literary culture of Anglo-Saxon England was first raised with respect to vernacular Anglo-Saxon literature, which is also, of course, the area in which the influence of texts which originated in so different a language is hardest to demonstrate. ${ }^{1} \mathrm{I}$ will discuss something of the evidence for knowledge of Ephraim in Old English texts later, for now, I want to turn to a more demonstrable, and just as important area of possible influence: the evidence which we have for the presence of a variety of Ephraimic and pseudoEphraimic writing in the library of Canterbury in the seventh century. This is the obvious place to start, since the presence of a number of Syriac and Greek works in this library, the contents of which formed part of a syllabus taught to an unknown number of Anglo-Saxon students, offers a clear and plausible avenue of transmission for such material into the far West.

The background to this Syriac influence on the teaching of Canterbury must be sought initially in Rome, and requires a brief outline of early Anglo-Saxon religious history. The year 667 was one of crisis for the young English Church. After the Roman missionary Augustine himself, the archbishopric was held by a series of those who had accompanied him on the English mission, Laurentius, Mellitus, Justus and Honorius. The sixth abbot, Deusdedit, was the first to be Anglo-Saxon by race, and was consecrated in 655. He ruled the Church-or at least, that part of it which considered a bishop in Kent relevant to its concerns-for nine years, and then died. In 664, a man called Wigheard, who had been one of Deusdedit's own clerics, was sent to Rome to be consecrated bishop, but while he was there, he died of the plague. Vitalian, who was Pope at the time, gave the problem his deep consideration. Clearly, he would have to send the English back an archbishop. The English church was in disarray and division: when the tempestuous and strong-willed future Archbishop of York, Wilfred, sought ordination in 664, there was only one bishop surviving in England, Berhtgisl/Boniface of East Anglia, who could not be objected to on either moral or orthodox grounds. Such a situation could not be allowed to continue. Vitalian's first choice was Hadrian, was then abbot of Hiridanum near Naples,

1 T.H. Bestul, "Ephraim the Syrian and Old English poetry," Anglia 99 (1981): 1-24. 
whom Bede describes as "a man of African race, well versed in the Holy Scriptures, trained both in monastic and ecclesiastical ways, and equally skilled in the Greek and Latin tongues." He was selected for these obvious virtues, and also because he had twice travelled in Frankia on various missions, and so had some sense of how to deal with people of Germanic culture. Hadrian demurred, and suggested two other names. The first, a monk called Andrew, was dismissed from consideration on grounds of his frail health. The second person he suggested, a friend of his, was something of a paragon: a learned monk from Tarsus in Cilica, learned in Greek and Latin literature, both secular and divine, whose name was Theodore. The only possible problem which he presented was that, being an Eastener by birth and upbringing, he might possibly teach doctrines accepted by the Greek Orthodox church, but not by the Catholics. This misgiving was solved by co-opting Hadrian to keep an eye on him. Theodore was consecrated by Vitalian in 668: he was then sixty-six years old. Hadrian was to be abbot of the monastery at Canterbury, then dedicated to Peter and Paul, which later became St. Augustine's. ${ }^{2}$

It is reasonable to assume that this elderly and distinguished Greek was appointed as a caretaker ministry. The most reasonable forecast which could have been made was that if the work did not kill him, the climate would. But, as it happened, he was proof against both. Theodore made a circuit of the whole of England shortly after his arrival, and became, says Bede, "the first of the archbishops whom the whole English Church consented to obey." In the years that followed, Theodore completely tranformed the church entrusted to his care. He instructed clerics and monks throughout England in their chosen way of life, introduced the knowledge of sacred music to English churches, and consecrated bishops wherever this was appropriate. He ruled the English church, as it had never been ruled before, for more than twentyone years, dying only in 690 .

It is this learned pair, Byzantine Christians by origin and formation, who were almost certainly responsible for bringing the knowledge of Ephraim to Anglo-Saxon England. It is probable, though not certain, that Theodore knew Syriac. Antioch, the

2 This account is paraphrased from our principal source for Theodore's life in England, Bertram Colgrave and R.A.B. Mynors (eds.), Bede, Historia Ecclesiastica gentis Anglorum IV.1 (Oxford, 1969) 328-33. 
nearest school of any importance to Theodore's native city of Tarsus, is the most likely place where the young Theodore may have begun his extensive education, and it was a city where both Greek and Syriac were in daily use in the sixth and seventh centuries. He may even have been to Edessa: a gloss on Numbers XI.5 from the Canterbury biblical commentaries notes:
cucumeres et pepones unum sunt, sed tamen cucumeres dicuntur pepones cum magni fiunt; ac saepe in uno pepone fiunt .xxx. librae. In Edissia ciuitate fiunt ut uix potest duo portare unus camelus.
Cucumbers and melons are the same thing, but cucumeres are called pepones when they get large; often, a single pepon will weigh thirty pounds. In the city of Edessa, they get so large that one camel can hardly carry two of them.

The fact that the Persian saint Milus of Susa, whose life was not translated into Greek, is included in the Old English Martyrology, with the place names in corrupt Syriac forms suggests that this text, for one, might actually have come to England in its original language: if it did, Theodore is the most likely person to have brought it. ${ }^{3}$ It would hardly be surprising if Theodore knew Syriac. In his later life, he was clearly a man with a gift for languages: besides his native Greek, and the Latin he acquired in his middle years, he learned Old English in his old age, and a complicated pun in a work which I have suggested was written by him, suggests that he may even have picked up a little Irish. ${ }^{4}$ But if anyone is reluctant to concede this hypothesis, it is in any case, likely that many of Ephraim's works had acquired Greek

${ }^{3}$ Christopher Hohler, "Theodore and the Liturgy," in M. Lapidge (ed.), Archbishop Theodore (Cambridge, 1995) 222-35, p. 225, and discussion by Günter Kotzor, Das altenglische Martyrologium (Bayerische Akademie der Wissenschaften, phil.-hist. Klasse, Abhandlungen ns 88; Munich, 1981) II, 370.

${ }^{4}$ In the Laterculus, he refers to "Scottorum scolaces:" the twisty reasoners of the Irish, if we read scolaces as a substitution of the plural of scolax, "twisted," for scholares_or "Irish whelps," if the play is on Greek skblax, pl. skblakes, "puppy" - or "babbling Irishmen," if it is on Irish scullacb: gossiping, prattling. Or all three. Jane Stevenson, The "Laterculus Malalianus" and the School of Archbishop Theodore (Cambridge, 1995) 163. 
translations by the seventh century, and that he knew Greek is beyond any possibility of doubt.

The use of Ephraimic texts at Canterbury is witnessed in a number of ways. I want to start with the most extensive, the several sets of glosses on parts of the Bible which emanate from the Canterbury school. These appear to be notes made from Theodore and Hadrian's exposition of Biblical texts in the monastery school: they can be thus identified, because the names of Theodore and Hadrian occur throughout. For example, the "Leiden Glossary," which is a member of this family of glossaries, contains an explanation of the word cyneris ("harps") in Ecclesiasticus 39: 20, as follows.

Cyneris. nabla. idest citharis longiores quam psalterium. Nam psalterium triangulum fit. Theodorus dixit.

Harps: nabla. That is, citharas. [They are] longer than a psaltery, for a psaltery should be triangular. Theodore said so.

In St. Gallen, Stiftsbibliothek 913, another member of this family of glosses, the bird larum, which occurs in Leviticus 11: 16, is glossed as follows: "Larum. hragra. Adrianus dicit meum esse." "Larum, a heron. Hadrian says it is a mew"- that is, a seamew, or seagull. This particular gloss is also interesting since it makes it clear that Hadrian used Old English in the classroom, and had a fair command of that language: Meus is not a Latin substantive (to translate the phrase as "Hadrian said it is mine" is to create obvious nonsense), but the Old English word for gull is maw. ${ }^{5}$

The biblical exegesis practised at Canterbury, as witnessed by these glossaries, was based mainly on Greek authorities. The tendency of the glosses is well witnessed by the examples quoted: they are for the most part historical, literally informative about things, actions, events and places unfamiliar to Anglo-Saxons, or philological, rather than allegorising-which is to say, they belong to the Antiochene school. 6 At a number of points, the Biblical

5 E. Steinmeyer and E. Sievers, Die althochdeutschen Glossen, 5 vols. (Berlin, 1879-22) IV, 460.

${ }^{6}$ Antiochene exegesis is by no means common in the early medieval West: for an overview, see M.L.W. Laistner, "Antiochene Exegesis in Western Europe during the Middle Ages," Harvard Theological Review 40 (1947): 19-32. 
Commentaries draw, whether directly or indirectly, on ideas which are first found in Ephraim.

Perhaps the best place to start in the Biblical Commentaries is with the one place where Ephraim is cited by name.

Ev. II,29 [Matth. 13: 46] Margarita grece, latine gemma. Effrem dicit quod in Mari Rubro concae a profundo natantes super aquas quae, facto tonitruo et fulgore intranteque ictu fulgoris, ita se concludentes concipiant et efficiant margaritam. Ita et Maria concepit sermonem Dei.

"Pearl" in Greek, in latin, "a gem." Ephraim says that in the Red Sea there are shellfish which swim from the bottom to the surface of the water, which, when there is thunder and lightning, are struck and entered by the lightning-bolt. Then they close themselves up, conceive, and produce a pearl. Thus did Mary conceive the Word of God.

As is so often the case with texts attributed to Ephraim in Greek and Latin, this cannot be located in any of his actual works. It appears to derive from a Greek Sermo adversus haereticos loosely based on one of Ephraim's Syriac hymns On Faith, thought to have been produced at the time of the Henotikon in the late fifth century by an adherent of the Chalcedonian party. ${ }^{7}$ Ephraim himself gives some thought to pearls, in his great hymns on the pearl. Pearls were of course loved by both the Romans and the Jews, and had acquired an enormous weight of symbolic significance by his day. In Ephraim's account, he specifically avoids making any kind of scientific explanation for the renowned lustre of orient pearls from the Red Sea: he is content to leave a mystery as a mystery: I give here the version in Assemani, and a translation. ${ }^{8}$

Attendite margaritae, et nolite errare... Fulgur et aqua in unum consenserunt, et duo se contraria complexa sunt... Ex igne fulgur et ignis unde et illuminat, et inflammat. Conchae ex aqua, et per aquam crescunt... Quomodo substantialiter atque essentialiter conveniunt

${ }^{7}$ Michael Lapidge and Bernhard Bischoff, Biblical Commentaries from the Canterbury School of Theodore and Hadrian (Cambridge, 1994) 514.

8 In G.S. Assemani et al. (eds.), Sancti Ephraim Syri Opera Omnia (Graece), 6 vols. (Rome, 1732-46) II, 268. 
aqua et ignis, ac se invicem non corrumpunt? Non potes dicere: sed cogeris credere quod vides et tangis.

Consider the pearl, and do not misinterpret... Lightning and water come together in one, and two contraries are embraced in it... From lightning-flash and fire it takes its lustre, and burns. Shellfish come from the water, and grow by water... How may water and fire come together, both in substance and in essence, and not mutually destroy one another?-you cannot say; but you are compelled to believe what you can see and touch.

Ephraim is more concerned with typological depth than with natural science; though he does make the point, found in the Biblical Commentaries, that the genesis of pearls is analogous to the conception of Christ, and therefore a symbol of it. ${ }^{9}$ But it is clear that Theodore and Hadrian are in this passage drawing on the Greek homily not the Syriac original, where the resemblance is much clearer. The very confident attribution to Ephraim in the gloss might derive from a false attribution in the copy of the sermo adversus baereticos which they possessed: alternatively, it is not impossible that in addition to the Greek text before him (or in his recent memory), Theodore might have read Ephraim's Hymns on the Pearl in Syriac early in his career, perhaps at Antioch or even Edessa, and been convinced, on that basis, that Ephraim was the ultimate source.

Though Ephraim is not otherwise cited by name, his work is clearly relevant at a number of other points in the Biblical Commentaries. For example, Ephraim's Commentary on Genesis was not so far as is known, translated into Greek, and certainly not into Latin. We need therefore to look at passages apparently dependent on this work with particular care. In discussing God's command "Let there be light," in Gen. 1: 3, the Commentator distinguishes between this light of three days duration, and the light which only later came into existence with the sun and moon (PentI, 23): a distinction which appears to originate in Ephraim's Commentary on

9 E. Beck (ed.), Des heiligen Ephraim des Syrers hymnen de fide, 2 vols. (CSCO 154-5, Script. Syr. 73-4; Louvain, 1955) II, 214 (= Hymni de margarita, no. lxxxii, strophes 1-2). 
Genesis. ${ }^{10}$ The Commentary on Genesis may be relevant elsewhere in the Biblical Commentaries: note that in PentI, 29, the creation of man in the image of God is felt to square poorly with the Bible's subsequent statement that the "image of God" was twofold: that of man and woman. This point is made by Ephraim: "Man/Adam, who was made one, and two: he was made one when Adam was made, and he was made two when 'male and female created he them'." 11

There is an interesting overlap between the Biblical Commentaries and part of the pseudo-Ephraimic corpus. A Syriac homily attributed to Ephraim, written in the sixth century, is unusual in conflating the tree of life and the tree of the knowledge of good and evil in the same way that the Commentator does in PentI 36, and in closely parallel wording. ${ }^{12}$ This is an unusual bringing together of ideas: though a number of Greek theologians link God with the Tree of Life; they do not identify him with the Tree of Knowledge.

PentI 36 [Genesis 2: 9] Et Deus est lignum vitae et scientiae boni malique; si bene sentimus et intellegimus de eo, hoc est de sancta trinitate, nobis erit lignum vitae.

God is the tree of life and the tree of the knowledge of good and evil: if we think and understand about him properly, that is, about the holy trinity, he will be a tree of life for us.

The Syriac homily offers the following perception:

Deus enim arbor scientiae boni et mali recte dicitur, idemque est arbor vitae; et siquidem parentes nostri paruissent, utique arborem scientiae boni, et lignum vitae, sibi Deum fuissent experti; atque ad iucundissimam contemplationem provecti fuissent, in

${ }^{10}$ Ephraim, Commentarius in Genesim I.9, in R-M. Tonneau (ed.), Sancti Ephraim Syri in Genesim et in Exodum Commentarii (CSCO 152-3, Scriptores Syri 71-2 ; Louvain, 1955) 9.

11 "Adam, qui unus factus est et duo: unus fuit qui Adam fuit, duo fuit qui masculus et femina creatus est." Commentarius in Genesim II.12, Tonneau, p. 24.

12 "De paradiso terrestri, et arbore scientiae boni et mali," Assemani, Sancti Ephraim Syri Opera, I, 129. 
ligno vitae repositam, quod est ipse Deus unus et trinus.

God is rightly called the tree of the knowledge of good and evil, which is the same as the tree of life, and if only our parents had conceded [this], then certainly God would have given the experience of the tree of the knowledge of good and the tree of life to them, and it would have brought them to the most delightful contemplation, found in the tree of life, which is God himself, both three and one.

The Canterbury text seems here to be a highly compressed summary of the Syrian homily (which is not known to have existed in a Greek version, let alone a Latin one): the two trees are identified, and thinking about them is identified with contemplating the Trinity. Note that the Syriac text also mentions God as "both three and one." Another minor point which may support the thesis that Ephraim's works were among Theodore and Hadrian's reading is that in PentI 62, Enoch is said to have been transported to Paradise which, according to some commentators, was located on a high mountain. Ephraim is one of these commentators, since his first Hymn on Paradise states that Paradise was situated on a high mountain.

\section{LATERCULUS}

[16] I now want to turn to another text which I have argued emanates from Canterbury, and was actually written by Theodore himself, unlike the Biblical Commentaries, which are redactions of his teaching based on lecture notes. Known as the Laterculus Malalianus, this work is a study of the historical life of Christ, which translates the relevant part of the Chronicle of the sixth-century Antiochene, John Malalas, and then offers an exegesis of it in the Antiochene style: if this thesis is accepted, it would strengthen the evidence for Lapidge's suggestion that Theodore received part of his education in Antioch. ${ }^{13}$ As with the Biblical Commentaries, the majority of the sources on which its author (presumably Theodore) draws are Greek.

13 The Laterculus Malalianus and the School of Archbishop Theodore (Cambridge, 1995). 
In this text, as in the Biblical Commentaries, Ephraim is quoted once by name, in a chapter which examines the concept of the Ordines Christi - that is, the idea that Christ, in his own lifetime, experienced, and therefore consecrated, all the orders of the church, from minor to major. The Laterculus gives seven grades, though it claims to give six: doorkeeper, gravedigger, reader, subdeacon, deacon, priest, and bishop, ending the passage with the comment: "Et haec quidem etiam sanctus Ephraim commemorat similiter." "And saint Ephraim comments similarly on this subject." Ordines Christi texts vary considerably. While everyone was sure that priests and bishops belonged in it, minor grades such as exorcists, doorkeepers and gravediggers were added or omitted depending on the judgment of the individual writer, and almost no two lists are quite the same. For example, a fourth-century pseudepigraphic "letter of Ignatius to the Antiochenes' lists presbyter, deacon, subdeacon, lector, cantor, doorkeeper, gravedigger, exorcist and confessor: the list given by Epiphanius, late in the same century, is of bishop, presbyter, deacon, subdeacon, lector, exorcist, interpreter, gravedigger and doorkeeper. ${ }^{14}$ The version of the Ordines Christi in the Laterculus should therefore give some indication of where it came from, which it does: the grades and their sequence given in the Laterculus are most like the sequences preserved in the Ethiopic version of Didascalia Apostolorum and in the interpolated Didascalia in the Constitutiones Apostolorum (which originated in Antioch or there abouts in the late fourth century). ${ }^{15}$ The reference here to an Ephraimic version of the Ordines Christi cannot be traced to a surviving work of Ephraim, but the origin of the text which lies behind this passage in the Laterculus was certainly Eastern, and probably Syriac. There are several Syriac witnesses to the ordinals of Christ, similar, though not identical to the version before us. It is not hard to believe that the text before the author of Laterculus bore an attribution to Ephraim.

[18] In any case, even though respect for the authority of Ephraim is all that is witnessed by the "ordinals of Christ" episode, actual knowledge of his works is found elsewhere in the Laterculus. For example, "it was the opinion of Mar Ephraim that the Magi came

${ }_{14}$ R.E. Reynolds, The Ordinals of Christ from their Origin to the Twelfth Century (Berlin, 1978) 15. Epiphanius's list is in his Expositio fidei, an addendum to his Panarion (Patrologia Graeca 42, 824).

15 See Reynolds, Ordinals of Christ, 11-3. 
to Bethlehem two years after the birth of Christ' according to the fragments of his commentary on the Gospels collected by Rendel Harris. ${ }^{16}$ This is the opinion held by the author of the Laterculus, $\int 5$. The story of the spontaneous destruction of the idols of Egypt as Christ entered that country with his parents, fleeing Herod, is mentioned in Laterculus, $\mathbb{} 7$ and appears twice in the collected works of Ephraim. ${ }^{17}$ This was an infancy tale widely known in the East (it also appears in the Akathistos hymn, for example), but the first version of Ephraim is the closest to that in the Laterculus: it includes the phrase, "virginis ulnis Aegypto invectus est" "He was carried to Egypt in the arms of the Virgin," equivalent to the formulation in the Laterculus, "ad adventum enim salvatoris sedentissuper gremium virginis matris" "at the arrival of the Saviour seated on the lap of his virgin mother..."

[19] That is a small point. It is perhaps more interesting that the concept that the virgin earth from which the protoplasts were made, should be typologically paralleled with the Virgin, appears in the Laterculus, and is found several times in Ephraim. ${ }^{18}$

The virginal earth bore that Adam/man, the head of the earth

The Virgin bore today [the second] Adam, the head of heaven

Thou, O my Lord, teach me how and why

it pleased thee to appear from a virginal womb,

$16 \mathrm{~J}$. Rendel Harris, Fragments of the Commentary of Ephrem Syrus upon the Diatessaron (London, 1895) 37: see now C. McCarthy, St. Ephrem's Commentary on Tatian's Diatessaron (Journal of Semitic Studies Supplement 2) and for the text, L. Leloir, Saint Ephraim, Commentaire de l'Evangile Concordant: Texte syriaque (MS Chester Beatty 709) (Dublin, 1963) and Saint Ephraim, Commentaire de l'Evangile Concordant: Texte syriaque (MS Chester Beatty 709), Folios additionels (Chester Beatty Monographs 8; 1990).

${ }^{17}$ Assemani, Sancti Ephraim Syri Opera, II, 49-50, and 144-5.

${ }^{18}$ Hymni de nativitate I.xvi and II, xii,1-4, E. Beck (ed. \& trans.), Des heiligen Ephraim des Syrers Hymnen de nativitate (CSCO 186-7, Script. Syr. 85-3; Louvain, 1959) 3 and 14: translations here from T. Kronholm, Motifs from Genesis 1-11 in the Genuine Hymns of Ephrem the Syrian, with Particular Reference to the Influence of Jewish Exegetical Tradition (Uppsala, 1978) 55. See further R. Murray, "Mary, the Second Eve in the Early Syriac Fathers," Eastern Churches Review 3 (1970/1):372-84. 
was its typos that of the pure/glorious Adam/man, who from the ground

the virginal, not yet tilled, received his form?

This elaboration of the ancient parallelism between Eve and Mary appears to belong both to the Greek and Syrica patristic traditions: it is, for example, found in Chrysostom ${ }^{19}$ so it is not peculiar to Ephraim, though it is an idea he returns to several times. The opposition of Eve and Mary, Adam and Christ, is worked out in similar terms in Laterculus $\$ 12$.

The idea that it was Christ who made man in his own image, not God the Father, is important to Ephraim, and in Laterculus:20 "as the First-born imago Dei invisibilis and primogenitusomnis creaturae, Christ functions as the mediator, voice and hand of the divine Majesty in every aspect of the creation of the world and the living creatures. However, he acts above all as the creating agent of the triune God in forming Adam/man into imago imaginis Dei." Similarly, in Laterculus $\ 12$, it is Christ who forms Adam, and "makes him in his own image:" "ad suam fecit imaginem."

Ephraim's favourite metaphor for Christ, "The Physician," 21 is implied in Laterculus $\$ 14$, and found in the letter of Archbishop Theodore to Æthelred in 686,22 and in the preface to the Penitential of Theodore's discipulus Umbrensium. ${ }^{23}$ Theodore himself, of course, was passionately interested in medicine: many of the Canterbury texts bear witness to this, and so does Bede. A more interesting, and more decisive instance of connection between Canterbury and Ephraim is the treatment of the "cornerstone" in the Laterculus. Ephraim's exegesis of this image in his Exposition of the Gospel is rather unusual. ${ }^{24}$

'And David was not the corner, for one wall of the buildings was made in him, only circumcision. Now

${ }^{19}$ De mutatione nominum II.3, Patrologia Graeca 51, 113-56, at 129.

${ }^{20}$ Kronholm, Motifs from Genesis, 51.

${ }^{21}$ Robert Murray, Symbols of Church and Kingdom (Cambridge, 1975) 200.

22 A.W. Haddan and W. Stubbs (eds.), Councils and Ecclesiastical Documents relating to Great Britain and Ireland, 3 vols. (Oxford, 1869-78) III, 171.

${ }^{23}$ P.W. Finsterwalder (ed.), Die Canones Theodori Cantuarensis und ibre bberlieferungsformen (Weimar, 1929) 287.

${ }^{24}$ Ephraim's Exposition of the Gospel, ch. 6 (Saint Ephraim: an Exposition of the Gospel, trans. G.A. Egan (Louvain, 1968) 4). 
since Christ preached circumcision and uncircumcision, two walls were made from him, and he became the head/chief [i.e. the corner-stone?]."

Ephraim thus extends the metaphor of the corner stone in a most ingenious way, by considering the point that if there is a corner, it must be the corner of something. He therefore visualises two walls shooting off at different angles from him: Christ is the source of both, but they are tending in different directions. Exactly this point is made in Laterculus:

"cui iuncti duo parietes e diverso venientes condidit in semetipsocopulavit, scilicet populorum conexio Iudaeorum atque gentiliumpacem in utrosque perficiens" (\$14)

[Christ] from whom there are two conjoined walls, going in different directions, joined and originating in he himself, that is, a connection between the Jewish people and the gentiles, bringing peace between them.

Again, Ephraim's Commentarius in Genesim, a text which on the evidence of the Biblical Commentaries, seems to have been known at Canterbury, ${ }^{25}$ discusses the original kingly authority of Adam and its relationship to his free will:

"if they had been made as infants, as the profane say, they would not have blushed to find themselves naked. Nothing is said about Adam and his wife which does not suggest they were young adults. The names given by Adam (to the animals) suffice to persuade one of his wisdom, and that he is said to work and look after the garden is enough to indicate his vigour: the law imposed on him is a witness of his adult status."

This view is firmly endorsed in Laterculus, $₫ 17$.

Et sic quippe credendum est quia homo in primordio factus a Domino aetate legitimus et mente plenus et capacem rationis in qua uictoriam caperet, si mortis superasset auctorem. Et ideo namque pena mortis incurrit, quia non sub paruoli motu et infirmior sensui, sed plenus ratione, homo in paradysu deliquid $[s i c] . .$.

${ }^{25}$ Commentarius in Genesim, Tonneau, p. 24. 
It should be believed that man was made in the beginning by God appropriate in age and capable in mind and full of understanding with which he could have captured victory, if he had been able to overcome the author of death. And accordingly, he incurred the penalty of death, since he was not under the motion of a child and deficient in sense, but a person full of intelligence offending in paradise...

Ephraim is also interested in the paradox between God's mercifulness to man and man's mercilessness to God: the theme is found in Ephraim's hymns: "he who gives drink to all entered and experienced thirst;" 26 "Christ came as a slave to liberate freedom. He even endured being stricken on the face by servants so that 'he broke the yoke that was on the free'." 27 An exploration of this theme is found in Laterculus $\$ 20$.

To sum up: the evidence for the knowledge of Ephraim at Canterbury is naturally variable in quality. Some points of congruence are such that they could have come from Ephraim, or from a number of other sources, others are probable going on certain. What is most striking is that some of the most interesting parallels are from genuine works which were not, so far as we know, translated into Latin.

\section{OTHER EVIDENCE FOR EPHRAIM IN ANGLO-SAXON ENGLAND}

[28] The only Ephraimic text to appear in pre-Conquest English manuscripts is the so-called Sermo asceticus. There is a copy in London, Lambeth Palace 204, written in the first half of the eleventh century, and perhaps from Christ Church, Canterbury, or from Ely. ${ }^{28}$ This contains the Dialogues of Gregory the Great, and a copy of the Sermo asceticus, under the title "liber beati Efrem" (ff. 119v-129v). This work, originally in Greek, is based partly on some of Ephraim's hymns, and partly on two Syriac sermons of

\footnotetext{
${ }^{26}$ S. Brock, "The Poet as Theologian," Sobornost 7 (1977): 243-53, at 244.

27 S.J. Beggiani, Early Syriac Theology, with special reference to the Maronite tradition (New York, 1983) 66. See also Kronholm, Motifs, 102.

28 Helmut Gneuss, "A Preliminary List of Manuscripts written or owned in England up to 1100," Anglo-Saxon England 9 (1981): 1-60, p. 33 (no. 510).
} 
doubtful attribution. It was translated into Latin as early as the sixth century, and regularly attributed to Ephraim in the earliest manuscripts. ${ }^{29}$ Clearly, a manuscript so late can tell us very little about the history of this text in England: since the sermo asceticus was very popular throughout Europe, and survives in a very large number of manuscripts from the late sixth century onwards, it could have come to England at any time from the Conversion to the Norman Conquest.

It is probably appropriate to subdivide other evidence for the knowledge of Ephraim and his work by language. Texts written in Latin are, with only a few exceptions, attributable to monks or clerics, thus, to individuals who might conceivably, at whatever remove, have benefited from the introduction of real or pseudepigraphic writings by Ephraim into seventh-century Canterbury, or might have come across Latin works attributed to Ephraim such as the Sermo asceticus. Texts written in Old English are of less certain origin. Probably everything that we have was redacted by clerics — or it could not have survived - it is less certain that everything was composed by Latinate clerics. The Christian poems which I will mention seem likely products of a monastic or clerical culture, and it is probable that most of the anonymous authors read Latin, but not certain.

Let us begin with Latin texts. The so-called Book of Cerne (CUL Ll.1.10), a prayer-book written in Northumbria early in the ninth century, contains a Latin version of a section of the Sermo asceticus, 30 is copied with the title "Oratio ad Dominum sancti Effremis." 31 The rubric is affixed to item 46 in the collection, but Sims-Williams has shown it should properly pertain to item 45 . The context of this prayer in the manuscript is late-eighth-century, and specifically English: it precedes two prayers attributed to Alchfrith the anchorite. ${ }^{32}$ This would seem to suggest that it when it was

${ }^{29}$ Patrick Sims-Williams, "Thoughts on Ephraim the Syrian in AngloSaxon England," in M. Lapidge and H. Gneuss (eds.), Learning and Literature in Anglo-Saxon England (Cambridge, 1985) 205-26, p. 206, and see D. Hemmerdinger-Iliadou, "Éphrem grec — Éphrem latin," Dictionnaire de spiritualité, IV (1960) 800-19, col. 802.

30 A.B. Kuypers (ed.), The Prayer Book of Aedeluald the Bishop commonly called the Book of Cerne (Cambridge, 1902) 141-2.

31 Ibid.

32 Sims-Williams, “Thoughts on Ephrem,” 209-10. 
copied into Cerne, it had already circulated for some time in England. Three Continental copies of the same Latin version survive: in the so-called Officia per ferias from a mid-ninth-century St. Denis MS, ${ }^{33}$ in the Fleury prayer-book (Orléans, Bibliothèque municipale 184), and in a MS of Saint-Bertin dated to AD 99, the Psalter of Odbert, Boulogne-sur-Mer, Bibl. mun. 20) In the first and last of these, the prayer is attributed by name to Ephraim. ${ }^{34} \mathrm{It}$ probably also appeared in an eighth-century English prayer book, the Book of Nunnaminster (London, BL Harley 2965): at the foot of f. $33 \mathrm{v}$, just before a lost leaf, is the heading Sancta oratio, and an incipit: "Deus meus et saluator meus quare me dere..." Since the "Ephraim" prayer opens "Domine deus meus et saluator meus, quare me dereliquisti?" it seems very probable that this was the same prayer.

Another early, semi-liturgical book of a similar type (London, BL Harley 7653, written somewhere in Southumbria, probably Mercia, c. 800) contains a prayer, incompletely preserved, which is a Latin version of the conclusion of a Greek metrical text De penitentia, attributed to Ephraim. ${ }^{35}$ The Syriac original of this text, if it ever existed, does not appear to survive. Versions of this Latin prayer occur in continental prayer books under the rubric oratio sancti Effrem, e.g. in a prayer book from Tours datable to c. $800,{ }^{36}$ and in an eleventh century Italian prayer book from the Beneventan region, where it has the rubric Oratio S. Ephraim ad postulandum fontem lacrimarum. ${ }^{37}$ Thus, we have evidence for more than one prayer travelling under the name of Ephraim, and genuinely deriving from texts which were at least Greek, if not Syriac, in origin, found both in Anglo-Saxon England and on the Continent. There is also some evidence of a more indirect kind for the knowledge of these prayers. In the Royal prayer-book, BL Royal 2 A xx, the prayer on f. 32 addresses "lover of men, most kind God" (amator hominum, benignissime deus): this appears to echo a prayer beginning "Philanthrope, agathe..." in Greco-Latin Ephraimic

33 Patrologia Latina 101, 510-612, from Paris, BN lat. 1153, ff 1-98.

34 Sims-Williams, "Thoughts on Ephrem," 223-4.

35 Assemani, Sancti Ephraim Syri Opera, I, 148-53.

36 Troyes, Bibliothuque municipale 1742, ed A. Wilmart, Precum libelli quattuor aevi karolini (Rome, 1940) 14.

${ }^{37}$ Now Vatican City, Biblioteca apostolica vaticana Barberini lat. 497, see P. Salmon, Analecta liturgica (Studi e Testi 273; Vatican City, 1974) 143. 
literature, ${ }^{38}$ or perhapsthe Sermo asceticus, ${ }^{39}$ which also uses the phrase. The prayer as a whole is not a redaction of Ephraim, but the phrase, it seems, had been encountered by its author, and had stuck with him.

Patrick Sims-Williams has observed that the personified deeds which reproach the monk of Wenlock in the vision reported by Boniface are an unusual element in the extensive literature of otherworld journeys, but may be paralleled by those that appear in the pseudo-Ephraimic opusculum De beatitudine animae. ${ }^{40}$ In this text, when the angels come to take the dying man's soul from his body, all its good and evil deeds committed by day and night appear, and stand by. The sinful soul is frightened both to see and to hear them, and begs for an hour's respite, but they reply, "you did us. We are your deeds. We will always accompany you. We will go to God together with you." 41 The monk of Wenlock similarly found himself confronted by his own personified sins, backed up by demons: he is defended by his virtues, supported by angels. This letter was written in the eighth century: so if Sims-Williams is correct in thinking that either the monk of Wenlock's experiences themselves, or the way they were written up, owed something to this opusculum, it was in Anglo-Saxon England from an early date.

Now I want briefly to discuss vernacular literature. It has been suggested in various contexts for the last century, most notably with respect to the so-called "Soul and Body" poems (which are Old English versions of an Ephraimic prototype, redacted through an unknown set of intermediaries) that Ephraim is an influence on

38 Assemani, Sancti Ephraim Syri Opera, I, 53, and III, 362.

39 The text in BL Harley 3060, f. 168r, headed "Oratio Donni Effrem," also includes the phrase "Amator hominum benignissime" (Sims-Williams, “Thoughts on Ephrem," 221-2).

40 Sims-Williams, "Thoughts on Ephrem," 207-8, n. 15: see M. Tangl (ed.), Die Briefe des heiligen Bonifatius und Lullus (MGH, epist. select. I; Berlin, 1916), ep. 10, pp. 9-10, and BL Harley 3060, f. 129 (quoted by SimsWilliams). This ninth-century manuscript contains the opuscula and a number of Spanish works: it cannot be used as evidence in itself for the knowledge of these texts in England since there is nothing to show that it entered the country any earlier than the seventeenth century.

41 Patrick Sims-Williams, Religion and Literature in Western England, 600-800 (Cambridge, 1990) 258-9. 
vernacular Old English literature. ${ }^{42}$ It has also been suggested that the poem known as "Christ III," on the theme of the Last Judgment, is in some fashion indebted to a metrical homily surviving in Greek, but accepted as a version of an original homily by Ephraim himself, De iudicio et compunctione. ${ }^{43}$ Arguments have also been made for an Ephraimic influence on Elene and Guthlac. ${ }^{44}$ Patrick Sims-Williams has commented, additionally, that "it may be wondered whether it is only the relative inaccessibility of the Latin 'Ephrem' that has prevented students of late Old English prose from finding sources there." 45

Bestul, who has made the fullest investigation of the Old English evidence, has concluded in the negative. He very properly points out that earlier investigators have tended to treat the Latin text in Assemani (which is actually a careless redaction of the seventeenth-century translation by Gerard Vossius) as if it represented "Ephraim:" that is, that it was available to AngloSaxon scholars in something like that form. This is obviously unsatisfactory. He therefore concludes that: ${ }^{46}$

While further study of the Latin text of Ephraim and Old English poetry may yield new information, for the

42 T. Batiouchkof, "Le Débat de l'âme et du corps," Romania 20 (1891): 1-55, 513-78: a likely intermediary is the Latin homily on this theme in Paris, BN nat 2096 (52) printed by Batiouchkof on pp. 576-8 and discussed by Louise Dudley, "An Early Homily on the "Body and Soul' Theme," Journal of English and Germanic Philology 8 (1909): 225-6. See also Eleanor K. Heningham, "The Precursors of the Worcester Fragments," Proceedings of the Modern Language Association 55 (1940): 291307.

43 Assemani, Sancti Ephraim Syri Opera, II, pp. 50-6. It appears as Kilianus Piscator (ed.), Libri Sancti Effrem de Compunctione cordis, (Freiburg im Breisgau, ca. 1491-2), sig. L6r-L7v. The attribution to Ephraim is strengthened by internal evidence: it opens, "Dearest brothers, come and take my advice; always remember the counsel of sinful, ignorant Ephraim." See A.S. Cook, The Christ of Cynewnlf (Boston, 1909²) xlv and 189-90 (ref. to lines 1084ff); D.G. Calder \& M.J.B. Allen, Sources and Analogues of Old English Poetry (Cambridge and Totowa, NJ, 1976), and F.M. Biggs, The sources of Christ III: a Revision of Cook's Notes (Old English Newsletter subsidia 12; Binghamton, NY, 1986) 2-3 and passim.

${ }^{44}$ Noted by Bestul, "Ephraim," 17.

${ }^{45}$ Sims-Williams, "Thoughts on Ephrem," 207.

${ }^{46}$ Bestul, "Ephraim," 22. 


\begin{abstract}
present, taking into account the quality of Grau's parallels and his reliance upon works without a well established Latin textual tradition, it is reasonable to state that that there is little in favour of the view that Ephraim was a direct source for any Old English literary text.
\end{abstract}

The trouble with seeing this as the end of the story is that my own investigations of the Laterculus have led me to suggest that Theodore brought at least one Greek text into Canterbury, and created an ad hoc, literal, running Latin translation for classroom use. Carmela Franklin has put forward another, by suggesting that Theodore is a very possible author for the word-by-word translation of the Greek Passio Sancti Anastasii which circulated in Anglo-Saxon England and was rewritten by Bede. ${ }^{47}$ So we have at least a basis for suggesting that some Christian texts first entered England in the Greek language. Bestul simply dismisses the possibility that Theodore brought with him "a library of Greek authors." 48 Obviously, he could not know about Laterculus, or the Passio S. Anastasii, which have been studied only very recently, but it is very far from clear to me why he assumed an objection in principle. It took about two years to get Theodore on the road to Canterbury. The Pope was well aware that the Anglo-Saxon Church was so understaffed it was hovering on the verge of implosion: if there was ever a moment when funds might have been made available for such purposes as copying books, I would suggest that this was it. The Northumbrian Benedict Biscop was in Rome, and is unlikely to have left his superiors under any illusions about what they were to expect-and that ardent early English bibliophile and passionate educationalist will surely have stressed the point that the young English church was in dire need of intellectual ballast. I think that to dismiss the possibility that Theodore and Hadrian arrived with a substantial library quite so

47 P. Meyvaert and C. Franklin, "Has Bede's version of the Passio S. Anastasii come down to us in BHL 408?" Analecta Bollandiana 100 (1982): 373-400.

48 Bestul, "Ephraim," 13: "It is not improbable that Eastern ascetic materials passed from Italy, to a center such as Corbie... and then to Anglo-Saxon England. This is altogether more likely than presuming... that Archbishop Theodore brought with him a library of Greek authors." 
cavalierly is to misinterpret the concept of an authorised mission. ${ }^{49}$ Theodore was not a Patrick: not a man with a private, impelling vision who browbeat his superiors into letting him sort out the English Church, he was a distinguished elderly theologian who was entrusted with the task after considerable negotiation and sent on his way at a pace which permitted proper organisation.

That being said, I think that with vernacular texts, even more than with Latin, we have to be very careful to recognise the distinction between a source and an influence. I can quite see that Bestul's common sense revolts at the thought of the author of Christ III or Elena sitting sucking his quill at a desk piled high with Latin redactions of works by Ephraim the Syrian: so does mine. But it is not, therefore, impossible that some part of the education the poet in question had received derived, perhaps at second or third hand, from Ephraim. From the time of Theodore to that of King Alfred, there is some degree of continuity in Anglo-Saxon education. The Canterbury school taught men, such as Tobias of Rochester, who taught others in their turn. Classroom notebooks such as that of the Discipulus Umbrensium were treasured and copied-if they had not been, they would not survive to this day. Unsystematic, partial bits and scraps, a mere bricolage of the great tradition of Syriac poetry, could have found its way by this means into the miscellaneous lore which stocked the minds of poets such as Cynewulf and his anonymous colleagues.

Insofar as I can offer any conclusions, they are of a very interim nature. I am convinced that some texts wrongly attributed to Ephraim came to various parts of England in the seventh century in Greek dress, and perhaps, that some rightly so attributed also came to Canterbury. I also think it just plausible that some Syriac texts came to England in Syriac, and were translated, ad hoc and on the spot, into Theodore's vigorous, demotic Latin. It also seems clear that Latin versions of prayers attributed to Ephraim formed part of the common stock of material circulating between private prayerbooks in Western Europe around the year 800 . Beyond that, almost everything is debatable.

49 See Jane Stevenson, "Christianising the Northern Barbarians," in Jens Flemming Krwger and Helge-Rolf Naley (eds.), Nordsjuen - Handel, Religion og politikk. Karmuy-seminarene 1994 og 1995 (Stavanger, 1996) 16284, e.g. p. 169. 